\title{
MARINE RADIOCARBON RESERVOIR AGES IN SCOTTISH COASTAL AND FJORDIC WATERS
}

\author{
Alix G Cage ${ }^{1,2} \bullet$ Jan Heinemeier ${ }^{3} \cdot$ William E N Austin $^{1}$ \\ ABSTRACT. High freshwater inputs into Scottish sea lochs (fjords) combined with the restricted exchange between sea loch \\ basin water and coastal Atlantic water masses are likely to result in reduced regional marine radiocarbon reservoir ages (R[t]) \\ in these environments. To test this hypothesis, historical, museum-archived shells, collected live on known dates prior to \\ AD 1950 from coastal locations in NW Scotland, were ${ }^{14} \mathrm{C}$ dated to provide a means of determining $\mathrm{R}(\mathrm{t})$ and hence the \\ regional deviation $(\Delta \mathrm{R})$ from the modeled global surface ocean reservoir age $(R)$. The sea loch data, when combined with ${ }^{14} \mathrm{C}$ \\ dates from the Scottish west coast (Harkness 1983), yield a regional $\Delta \mathrm{R}$ value of $-26 \pm 14 \mathrm{yr}$. The $\Delta \mathrm{R}$ of sea loch (fjordic) and \\ coastal waters of NW Scotland are statistically different (at a confidence level $>95 \%$ ) from the $\Delta \mathrm{R}$ value of $17 \pm 14 \mathrm{yr}$ reported \\ for UK coastal waters (Reimer 2005; data after Harkness 1983) and are in good agreement with the coastal $\Delta \mathrm{R}$ value of $-33 \pm$ \\ $93 \mathrm{yr}$ reported by Reimer et al. (2002). Therefore, it is recommended that a regional $\Delta \mathrm{R}$ correction of $-26 \pm 14 \mathrm{yr}$ should be \\ applied to modern (i.e. pre-bomb but not prehistoric) marine ${ }^{14} \mathrm{C}$ dates from the NW coast of Scotland.
}

\section{INTRODUCTION}

Radiocarbon in the atmosphere is rapidly mixed, and organisms living in the terrestrial biosphere generally exhibit ${ }^{14} \mathrm{C}$ concentrations that are in equilibrium with atmospheric ${ }^{14} \mathrm{C}$ due to rapid gaseous exchange during life processes. Conversely, marine organisms typically deposit their carbonate shells close to isotopic equilibrium with seawater (e.g. Mook and Vogel 1968), primarily deriving carbon from the dissolved inorganic carbon available in the surrounding seawater. The ${ }^{14} \mathrm{C}$ concentration of marine shells therefore reflects the ${ }^{14} \mathrm{C}$ concentration of the seawater in which they live and calcify. Restricted replenishment of ${ }^{14} \mathrm{C}$ across the ocean-atmospheric boundary, along with the continual introduction of ${ }^{14} \mathrm{C}$-depleted deeper waters through mixing and upwelling, results in a ${ }^{14} \mathrm{C}$ deficiency in the mixed surface ocean relative to the atmosphere, so that marine organisms typically exhibit an apparent ${ }^{14} \mathrm{C}$ age excess compared to contemporaneous terrestrial organisms. The ${ }^{14} \mathrm{C}$ deficiency of a water mass is expressed by its marine ${ }^{14} \mathrm{C}$ reservoir age, $\mathrm{R}(\mathrm{t})$, which is determined by the difference between a measured marine ${ }^{14} \mathrm{C}$ age, ${ }^{14} \mathrm{C}_{\mathrm{M}}(\mathrm{t})$, obtained from marine carbonate material such as a mollusk, and the contemporaneous atmospheric ${ }^{14} \mathrm{C}$ age,${ }^{14} \mathrm{C}_{\mathrm{T}}(\mathrm{t})$, taken from the terrestrial calibration curve IntCal04 (Reimer et al. 2004):

$$
\mathrm{R}(\mathrm{t})={ }^{14} \mathrm{C}_{\mathrm{M}}(\mathrm{t})-{ }^{14} \mathrm{C}_{\mathrm{T}}(\mathrm{t})
$$

A reservoir age correction is typically applied to a conventional marine ${ }^{14} \mathrm{C}$ date in order to correct for growth in a non-atmospheric (i.e. marine) carbon reservoir (e.g. Stuiver et al. 1986). Stuiver et al. (1986) calculated a smooth calibration curve for the mixed layer of a model ocean. To accommodate local effects, they introduced the quantity $\Delta \mathrm{R}$, defined as the difference between the measured sample age and the global model curve. The standard modeled global average surface ocean reservoir age is approximately $400 \mathrm{yr}$ (Stuiver and Braziunas 1993). A first-order approximation is to replace $\mathrm{R}(\mathrm{t})$ by a constant (regional) value $\mathrm{R}^{*}$. This fixed reservoir correction, $\mathrm{R}^{*}$, is subtracted from the measured ${ }^{14} \mathrm{C}$ age of a marine sample prior to calibration by the terrestrial calibration curve. However, marine reservoir ages can vary geographically (Table 1; Berkman and Forman 1996; Bard et al. 1998; Facorellis et al. 1998; Siani et al. 2000; Yoneda et al. 2000) and, according to the model, temporally (e.g. Austin et al. 1995; Bard 1998; Waelbroeck et al. 2001).

\footnotetext{
${ }^{1}$ School of Geography and Geosciences, University of St. Andrews, St. Andrews, Fife KY16 9AL, United Kingdom. ${ }^{2}$ Corresponding author. Email: agc10@ st-andrews.ac.uk.

${ }^{3}$ AMS ${ }^{14} \mathrm{C}$ Dating Centre, Department of Physics and Astronomy, University of Aarhus, DK-8000 Aarhus C, Denmark.
} 
Table 1 Regional $\Delta \mathrm{R}$ values for the Northeast Atlantic shelf sea region. Also shown are the publications from which the data were derived.

\begin{tabular}{|c|c|c|c|}
\hline Location & Method & $\begin{array}{l}\text { Regional mean } \\
\Delta \mathrm{R} \text { value }\end{array}$ & References \\
\hline Spitsbergen & $\begin{array}{l}\text { Pre-bomb shells and } \\
\text { mammal bones collected } \\
\text { live in known year }\end{array}$ & $93 \pm 23 y^{a}$ & $\begin{array}{l}\text { Mangerud 1972; Mangerud } \\
\text { and Gulliksen 1975; Olsson } \\
1980\end{array}$ \\
\hline N Norway & $\begin{array}{l}\text { Pre-bomb shells collected } \\
\text { live in known year }\end{array}$ & $65 \pm 35 \mathrm{yr}^{\mathrm{a}}$ & Mangerud and Gulliksen 1975 \\
\hline $\begin{array}{l}\text { Iceland and Faroe } \\
\text { Islands }\end{array}$ & $\begin{array}{l}\text { Pre-bomb shells collected } \\
\text { live in known year }\end{array}$ & $52 \pm 19 \mathrm{yr}^{\mathrm{a}}$ & $\begin{array}{l}\text { Broecker and Olson 1961; } \\
\text { Krog and Tauber 1974; } \\
\text { Håkansson 1983, } 1984\end{array}$ \\
\hline $\begin{array}{l}\text { W coast of Nor- } \\
\text { way (including } \\
\text { fjordic samples) }\end{array}$ & $\begin{array}{l}\text { Pre-bomb shells collected } \\
\text { live in known year }\end{array}$ & $7 \pm 30 \mathrm{yr}$ & $\begin{array}{l}\text { Mangerud 1972; Mangerud } \\
\text { and Gulliksen } 1975\end{array}$ \\
\hline $\begin{array}{l}\text { SE Norway, W } \\
\text { Sweden, and E } \\
\text { Denmark }\end{array}$ & $\begin{array}{l}\text { Pre-bomb shells and } \\
\text { mammal bones collected } \\
\text { live in known year }\end{array}$ & $-10 \pm 16 \mathrm{yr}^{\mathrm{a}}$ & $\begin{array}{l}\text { Håkansson 1969; Olsson et al. } \\
\text { 1969; Håkansson 1970; } \\
\text { Mangerud 1972; Krog and } \\
\text { Tauber 1974; Mangerud and } \\
\text { Gulliksen 1975; Olsson 1980; } \\
\text { Heier-Nielsen et al. } 1995\end{array}$ \\
\hline Baltic Sea & Not known & $-107 \pm 24 y^{a}$ & $\begin{array}{l}\text { Engstrand 1965; Håkansson } \\
1987\end{array}$ \\
\hline $\begin{array}{l}\text { S Norway and } \\
\text { North Sea }\end{array}$ & $\begin{array}{l}\text { Pre-bomb shells collected } \\
\text { live in known year }\end{array}$ & $-3 \pm 27 \mathrm{yr}^{\mathrm{a}}$ & $\begin{array}{l}\text { Mangerud 1972; Mangerud } \\
\text { and Gulliksen 1975; Weidman } \\
1995\end{array}$ \\
\hline $\begin{array}{l}\text { Danish coastal } \\
\text { waters, including } \\
\text { fjords }\end{array}$ & $\begin{array}{l}\text { Pre-bomb shells collected } \\
\text { live in known year }\end{array}$ & $\begin{array}{l}\text { Coastal waters: } \\
\Delta \mathrm{R}=13 \pm 16 \mathrm{yr} \\
\text { Fjords: mean } \\
\Delta \mathrm{R}=279 \mathrm{yr}\end{array}$ & Heier-Nielsen et al. 1995 \\
\hline UK coastal waters & $\begin{array}{l}\text { Pre-bomb shells collected } \\
\text { in known year }\end{array}$ & $\Delta \mathrm{R}=17 \pm 14 \mathrm{yr}$ & Harkness 1983 \\
\hline $\begin{array}{l}\text { W coast Ireland, } \\
\text { W coast Scotland, } \\
\text { Outer Hebrides } \\
\text { and the Orkney } \\
\text { Islands }\end{array}$ & $\begin{array}{l}\text { Paired dating of marine } \\
\text { and terrestrial samples for } \\
\text { the past } 6100 \text { yr BP. Mate- } \\
\text { rial from archaeological } \\
\text { sites }\end{array}$ & $\Delta \mathrm{R}=-33 \pm 93 \mathrm{yr}$ & Reimer et al. 2002 \\
\hline
\end{tabular}


marine; Reimer 2005).

A more accurate procedure to correct sample ${ }^{14} \mathrm{C}$ ages for regional marine ${ }^{14} \mathrm{C}$ reservoir effects is therefore to determine the regional value of $\Delta \mathrm{R}$ and subtract it from the measured ${ }^{14} \mathrm{C}$ age prior to calibration with the model marine calibration curve, the latest version being Marine04 (Hughen et al. 2004a). $\Delta \mathrm{R}$ is defined as the difference between a measured marine ${ }^{14} \mathrm{C}$ age and the global model ${ }^{14} \mathrm{C}$ curve of the surface ocean $\left(R\right.$, obtained from the Marine $04{ }^{14} \mathrm{C}$ calibrations curves of Hughen et al. 2004a) and may be expressed as:

$$
\Delta \mathrm{R}={ }^{14} \mathrm{C}_{\mathrm{M}}(\mathrm{t})-\text { Marine04(t) }
$$


Modern pre-bomb $\mathrm{R}(\mathrm{t})$ and $\Delta \mathrm{R}$ values from sites across the globe, along with regional mean values, are reported on the online Marine Reservoir Correction Database compiled by Reimer (2005) and accessible at http://radiocarbon.pa.qub.ac.uk/marine/.

\section{Regional Deviations in Marine Reservoir Age $(\Delta \mathbf{R})$ Within Fjords}

Harkness (1983) calculated the average reservoir age of UK coastal waters to be $405 \pm 40 \mathrm{yr}$ based on measurements obtained from 14 locations, only 4 of which come from the west coast of Scotland. Unlike most coastal locations, the sea lochs of NW Scotland typically have a restricted connection with the adjacent shelf waters and also experience high freshwater inputs, which can dilute the salinity of bottom water masses (e.g. Farmer and Freeland 1983). An important characteristic of fjordic circulation is the occurrence of periodic deep-water renewal events (DWREs) that are usually forced by salinity thresholds, mixing processes, and wind speed and/or direction (e.g. Gillibrand et al. 1995). Gillibrand et al. (2005) demonstrated the influence of climatic forcing upon the frequency of DWREs, and Austin and Inall (2002) exemplified how DWREs could influence the isotopic composition of fjord water. The ${ }^{14} \mathrm{C} /{ }^{12} \mathrm{C}$ ratios of freshwater systems in igneous areas (such as NW Scotland) should be similar to atmospheric ratios (Broecker and Walton 1959) and are unlikely to be influenced by "hard water effects" from the surrounding bedrock geology in contrast to studies from other settings (e.g. Heier-Nielsen et al. 1995). Spiker (1980) reported a conservative ${ }^{14} \mathrm{C}$ :salinity relationship for estuarine waters, and the significant influence of fresh water in fjordic hydrography suggests that Scottish fjords are likely to exhibit reduced marine reservoir ages when compared to average UK coastal values. The $\Delta \mathrm{R}$ value of $17 \pm 14 \mathrm{yr}$ estimated for the coastal waters of the UK (Harkness 1983; data recalculated by Reimer 2005) should contrast with an expected negative $\Delta \mathrm{R}$ in Scottish sea lochs because coastal waters are mixed with relatively "young" fresh waters in these fjordic environments. Reimer et al. (2002) reported a $\Delta \mathrm{R}$ value of $-33 \pm 93 \mathrm{yr}$ for the coastal waters of Ireland, Scotland, and the Orkney Isles during the mid- to late Holocene, while Ascough et al. (2004) reported a $\Delta \mathrm{R}$ of $-79 \pm 17 \mathrm{yr}$ for $\mathrm{N}$ and W Scottish coastal waters at approximately $2000 \mathrm{BP}$.

Differences in sea loch bathymetries (e.g. sill and basin depths) and freshwater inputs mean that sea lochs typically exhibit a varying and complex hydrography (Farmer and Freeland 1983; Edwards and Sharples 1986). The frequency of DWREs and the resultant salinity of basin water is highly variable in Scottish sea lochs (e.g. Edwards and Sharples 1986; Gillibrand et al. 1995, 1996; Allen and Simpson 1998; Austin and Inall 2002); thus, sea lochs are likely to show different R(t) responses. Despite these differences, it would be advantageous to determine and use the average $\Delta R$ for Scottish sea lochs rather than the average UK coastal value of $\Delta \mathrm{R}$ currently available. Recent paleoclimate studies have focused on obtaining high-resolution paleoenvironmental records from NW European fjordic locations (e.g. Mikalsen et al. 2001; Kristensen et al. 2004), and there is therefore a growing need for improved understanding of both the spatial and temporal behavior of $\Delta \mathrm{R}$ in fjord environments. Even in shelf areas, $\Delta \mathrm{R}$ has been found to exhibit strong temporal variability (Eiríksson et al. 2004).

\section{METHODS}

\section{Sample Material}

In this study, the modern marine reservoir ages from locations around the west coast of Scotland were determined by ${ }^{14} \mathrm{C}$ dating 10 marine mollusk shells (obtained from the National Museum of Scotland, Edinburgh) collected "live" on known dates prior to AD 1950 (e.g. Mangerud 1972; Harkness 1983; Heier-Nielsen et al. 1995), i.e. the death of the mollusk is presumed to be contemporaneous with the collection year. Bivalves in pristine condition (periostracum intact and often articu- 
lated) from Loch Creran, Loch Fyne, Upper Loch Fyne, Tarbert, and Wemyss Bay were used (see Figure 1 for locations). Due to the general dearth of available archived shells from Scottish sea lochs, 2 shells from Oban (Firth of Lorne) were also ${ }^{14} \mathrm{C}$ dated. The Loch Creran bivalve (AAR7489 ) is not accompanied by a known collection year (Table 2); however, it was bequeathed to the National Museum by Alexander Somerville, who is known to have collected samples between AD 1843-1907, and the sample was included in the study to expand the available data from sea loch environments. Unfortunately, information on the water depth, temperature, and salinity did not accompany the shell samples. The majority of the mollusk species in this study are short lived $(<10 \mathrm{yr})$ and have reported habitats from the littoral to water depths of up to $100 \mathrm{~m}$. The preferred substrate tends to be mud or muddy sand, suggesting fairly low energy environments of deposition, i.e. water depths below spring low tide and beneath the influence of wave action.
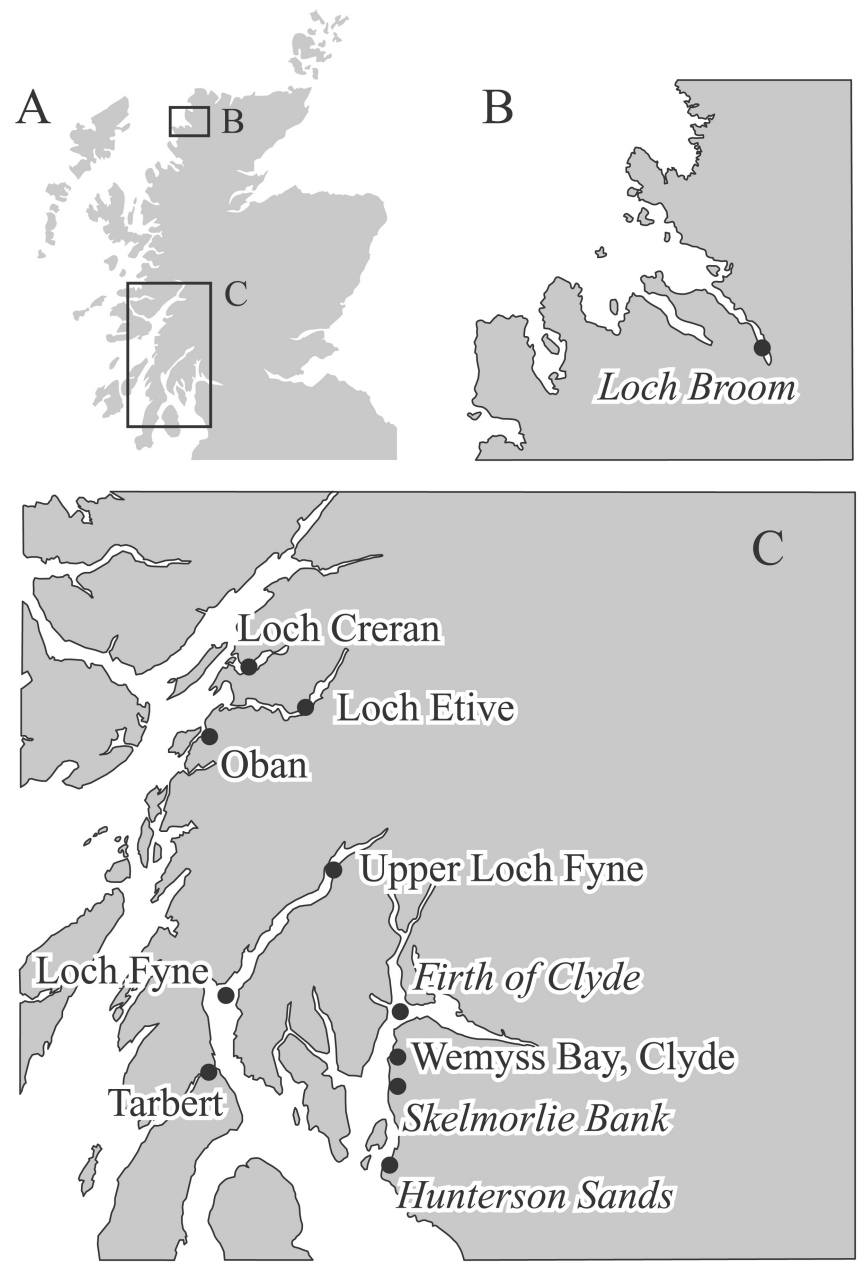

Figure 1 a) Map showing the 2 study areas, which are seen in detail in $b$ and $c$. The shells used in this study were collected from Loch Creran, Loch Fyne, Upper Loch Fyne, Tarbert, Wemyss Bay, and Oban by Alexander Somerville between AD 1843-1907. Shells used in the Harkness (1983) study were collected from Loch Broom, Skelmorlie Bank, Hunterston Sands, and the Firth of Clyde (locations shown in italics). 


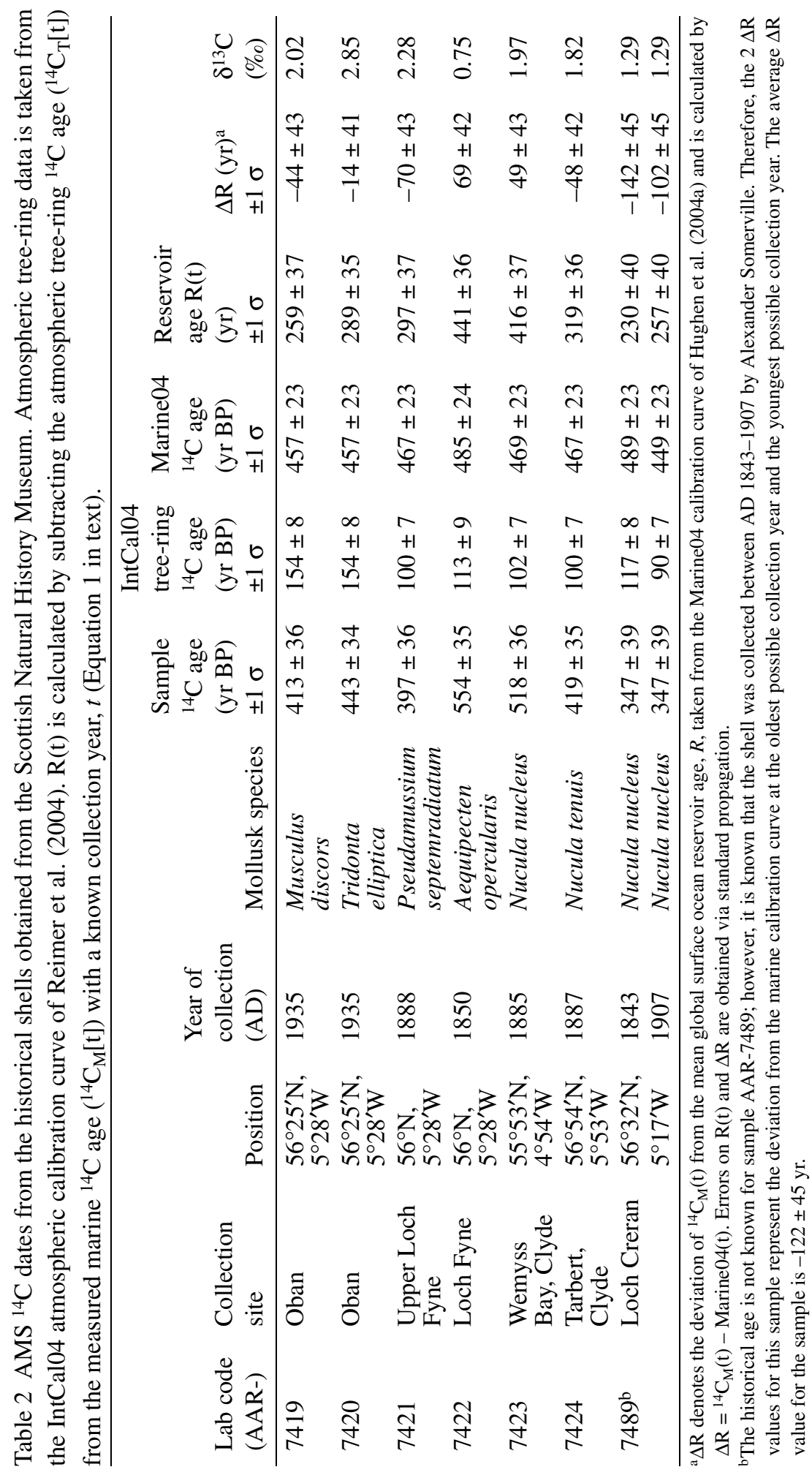




\section{Laboratory Methods}

Approximately $40 \mathrm{mg}$ of material was removed from each sample in preparation for accelerator mass spectrometry (AMS) dating, allowing sufficient material for potential pretreatment losses and enough carbon yield for a repeat analysis of the sample if required. The periostracum was scraped off the shells where possible and on the larger scallop shells (which are known to live for up to $6 \mathrm{yr}$ ) the outer growth bands were selected to ensure that the youngest shell material was obtained. Sample material was prepared for AMS dating using the techniques reported in Heier-Nielsen et al. (1995), i.e. cleaned, dried, and acid etched (using $1 \mathrm{M} \mathrm{HCl}$ ) to remove approximately $20-25 \%$ of the outer shell surface and thus possible surface contamination. The organic component was removed from the sample material by reduction methods (i.e. heating to $80^{\circ} \mathrm{C}$ for $12 \mathrm{hr}$ in a solution containing $\mathrm{KMnO}_{4}$ ). After cleaning and drying the sample, approximately $14 \mathrm{mg}$ of the prepared sample was used to generate $\mathrm{CO}_{2}$ gas. The $\mathrm{CO}_{2}$ was liberated using $\sim 100 \%$ phosphoric acid in an evacuated vial at $25^{\circ} \mathrm{C}$, and a portion of the $\mathrm{CO}_{2}$ gas was used for $\delta^{13} \mathrm{C}$ analysis (carried out by isotope ratio mass spectrometry at the Science Institute, Reykjavík, Iceland, by Dr Árný E Sveinbjörnsdóttir), while the rest was converted to graphite for AMS ${ }^{14} \mathrm{C}$ measurements via reduction with $\mathrm{H}_{2}$ using cobalt as a catalyst. A small reaction volume and a high initial pressure of the reacting gases were used (Vogel et al. 1984).

All AMS ${ }^{14} \mathrm{C}$ measurements were carried out using the EN tandem accelerator at the University of Aarhus (Denmark). The dating results are reported as conventional ${ }^{14} \mathrm{C}$ dates in ${ }^{14} \mathrm{C}$ yr $\mathrm{BP}$ (before AD 1950) based on the measured ${ }^{14} \mathrm{C} /{ }^{13} \mathrm{C}$ ratio corrected for the natural isotopic fractionation by normalizing the result to the standard $\delta^{13} \mathrm{C}$ value of $-25 \%$ PDB (Stuiver and Polach 1977; Andersen et al. 1989).

\section{RESULTS}

Marine bivalves, which were presumably collected "live" from Scottish west coast waters between AD 1843-1935, yielded measured AMS ${ }^{14} \mathrm{C}$ ages ranging from $347 \pm 39$ to $554 \pm 35{ }^{14} \mathrm{C}$ yr BP (Table 2). The weighted average ${ }^{14} \mathrm{C}$ age of the samples including the Loch Creran sample (AAR7489 ) is $444 \pm 14{ }^{14} \mathrm{C}$ yr BP, and $458 \pm 15{ }^{14} \mathrm{C}$ yr BP when the Loch Creran sample is excluded.

The calculated marine ${ }^{14} \mathrm{C}$ reservoir ages, $\mathrm{R}(\mathrm{t})$, and regional $\Delta \mathrm{R}$ values are presented in Table 2 . Scottish coastal and fjordic $\mathrm{R}(\mathrm{t})$ values range from $259 \pm 37 \mathrm{yr}$ for sample AAR-7419, collected from Oban in AD 1935, to $441 \pm 36 \mathrm{yr}$ for sample AAR-7422, collected from Loch Fyne in AD 1850 (Table 2). $\Delta \mathrm{R}$ values range from $-70 \pm 43$ yr for the Upper Loch Fyne sample (AAR-7421) to $69 \pm 42 \mathrm{yr}$ for the Loch Fyne sample (AAR-7422). Although the Loch Creran sample (AAR-7489) does not have a specific collection date (i.e. collected between AD 1843-1907), the $\Delta \mathrm{R}$ range (-142 $\pm 45 \mathrm{yr}$ for $\mathrm{AD} 1843$ to $-102 \pm 45 \mathrm{yr}$ for AD 1907) has been included to exemplify the extent to which these fjordic environments could deviate from $R$. Individual $\Delta \mathrm{R}$ values from this study range from $-122 \pm 45 \mathrm{yr}$ (mean $\Delta \mathrm{R}$ value for the Loch Creran sample) to $69 \pm 42{ }^{14} \mathrm{C} \mathrm{yr}$, giving a weighted average $\Delta \mathrm{R}$ value of $-9 \pm 18 \mathrm{yr}$ excluding the Loch Creran sample, and $-24 \pm 16 \mathrm{yr}$ when an averaged $\Delta \mathrm{R}$ for the Loch Creran sample is included. Five out of the $7 \Delta \mathrm{R}$ values fall below the global surface ocean average marine curve of $\Delta R=0$ (Figure 2). Figure 2 shows that the 2- $\sigma$ error range of all the $\Delta \mathrm{R}$ values (with the exception of the oldest possible Loch Creran date, AD 1843) intersect the 2- $\sigma$ error range of the weighted average $\Delta \mathrm{R}=-9 \pm 15 \mathrm{yr}$, suggesting that differences between the data are statistically insignificant at $95 \%$ confidence levels. The fact that the individual $\Delta \mathrm{R}$ values fall within the acceptable limits of the weighted average suggests that all data can be included in a regional average (Harkness 1983). 


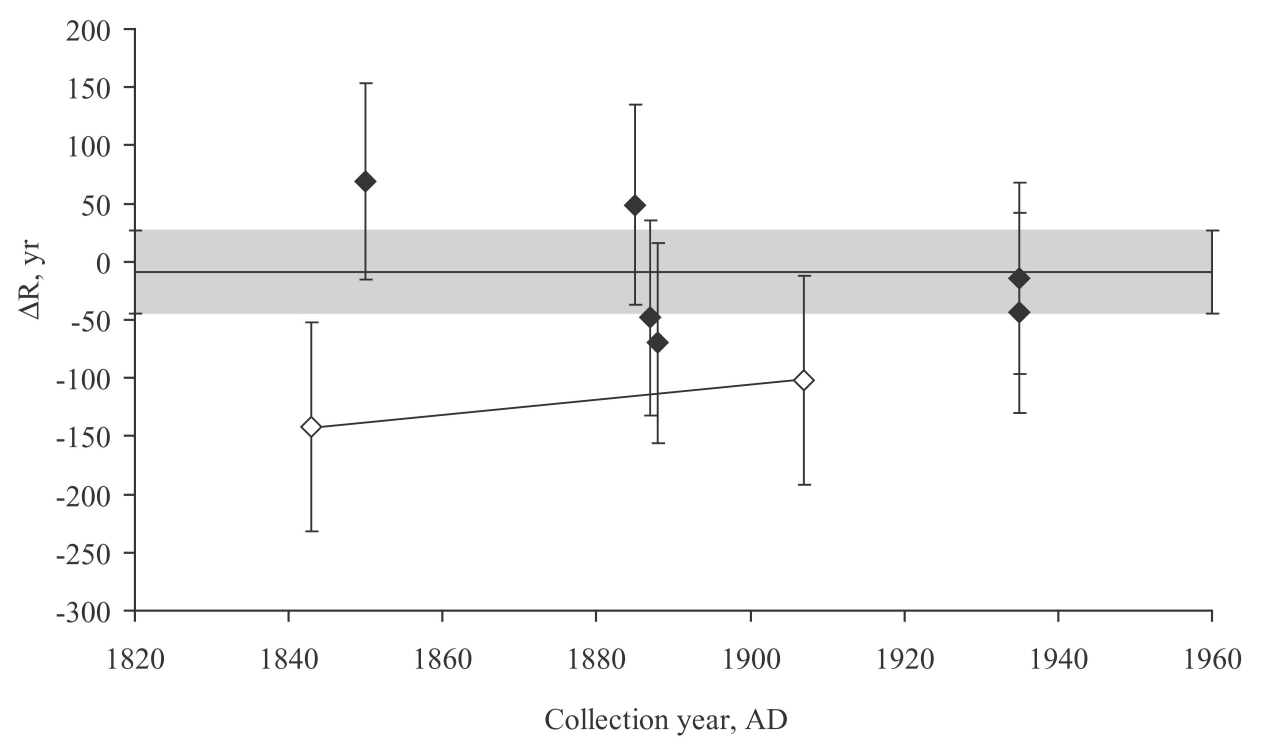

Figure 2 The $\Delta \mathrm{R}$ values of the historical, museum-archived, Scottish west coast shells (filled diamonds) plus the possible collection period of the Loch Creran sample (unfilled diamond linked by a line) with measured ${ }^{14} \mathrm{C}$ age errors of $2 \sigma$. The thick black line and shaded box represent the weighted average of the $\Delta \mathrm{R}$ values with $2-\sigma$ error bars $(\Delta \mathrm{R}=-9 \pm 18$; excluding the Loch Creran sample).

\section{DISCUSSION}

The weighted average $\Delta \mathrm{R}$ value for the fjordic samples from this study is $-9 \pm 18 \mathrm{yr}$ (or $-24 \pm 16 \mathrm{yr}$ when an averaged $\Delta \mathrm{R}$ for the Loch Creran sample is included). To improve the spatial coverage of the regional $\Delta \mathrm{R}$ value and add more sea loch or "restricted" environments to the relatively small data set $(n=7)$ presented in the previous section, ${ }^{14} \mathrm{C}$ reservoir data from Harkness (1983) were combined with data from this study (Table 3).

Harkness (1983) determined a marine ${ }^{14} \mathrm{C}$ reservoir age of $405 \pm 40{ }^{14} \mathrm{C}$ yr BP for UK coastal waters; however, this average included only 4 west Scotland sites (Table 3). Harkness highlighted samples SRR-170 (a+b) and SRR-356 (b; Table 3) as falling outside the acceptable statistical variance (2 $\sigma)$ for the group's mean apparent age of $405 \pm 40{ }^{14} \mathrm{C} \mathrm{yr} \mathrm{BP}$ (Table 3). However, these samples have been included in this study following the recalculation of Harkness' $(1983){ }^{14} \mathrm{C}$ ages by Reimer (2005; http://radiocarbon.pa.qub.ac.uk/marine/refs/132.html). Recalculation of the Harkness (1983) data by Reimer (2005) yields younger apparent ages because the latter have been calculated from the published $\Delta^{14} \mathrm{C}, \mathrm{D}^{14} \mathrm{C}$, or $\delta^{14} \mathrm{C}$ values and have been corrected for isotopic fractionation associated with anthropogenic activity.

The recalculated Harkness weighted average $R(t)$ for the Scottish west coast samples is $353 \pm 10{ }^{14} \mathrm{C}$ $\mathrm{yr} \mathrm{BP}(n=9)$ with sample $\Delta \mathrm{R}$ values ranging from $-120 \pm 54$ to $93 \pm 33 \mathrm{yr}$ (Table 3). Out of the 9 samples reported, 6 show negative $\Delta \mathrm{R}$ values, while samples SRR-356a, $-356 \mathrm{~b}$, and $-357 \mathrm{~b}$ exhibit positive $\Delta \mathrm{R}$ values greater than $\sim 70 \mathrm{yr}$ (Table 3 and Figure 3 ). All the shells used in this study and by Harkness (1983) were whole valves (often articulated), with no visual signs of deterioration, such as a powdery surface common as a result of recrystallization processes (Aitken 1990). Reimer et al. (2002) point out that molluskan feeding habits are important when interpreting $\delta^{13} \mathrm{C}$ and therefore ${ }^{14} \mathrm{C}$ data, since this may influence how carbon with different ${ }^{14} \mathrm{C}$ signatures enters the organism. For example, filter-feeders obtain carbon directly from seawater in the form of dissolved inorganic car- 


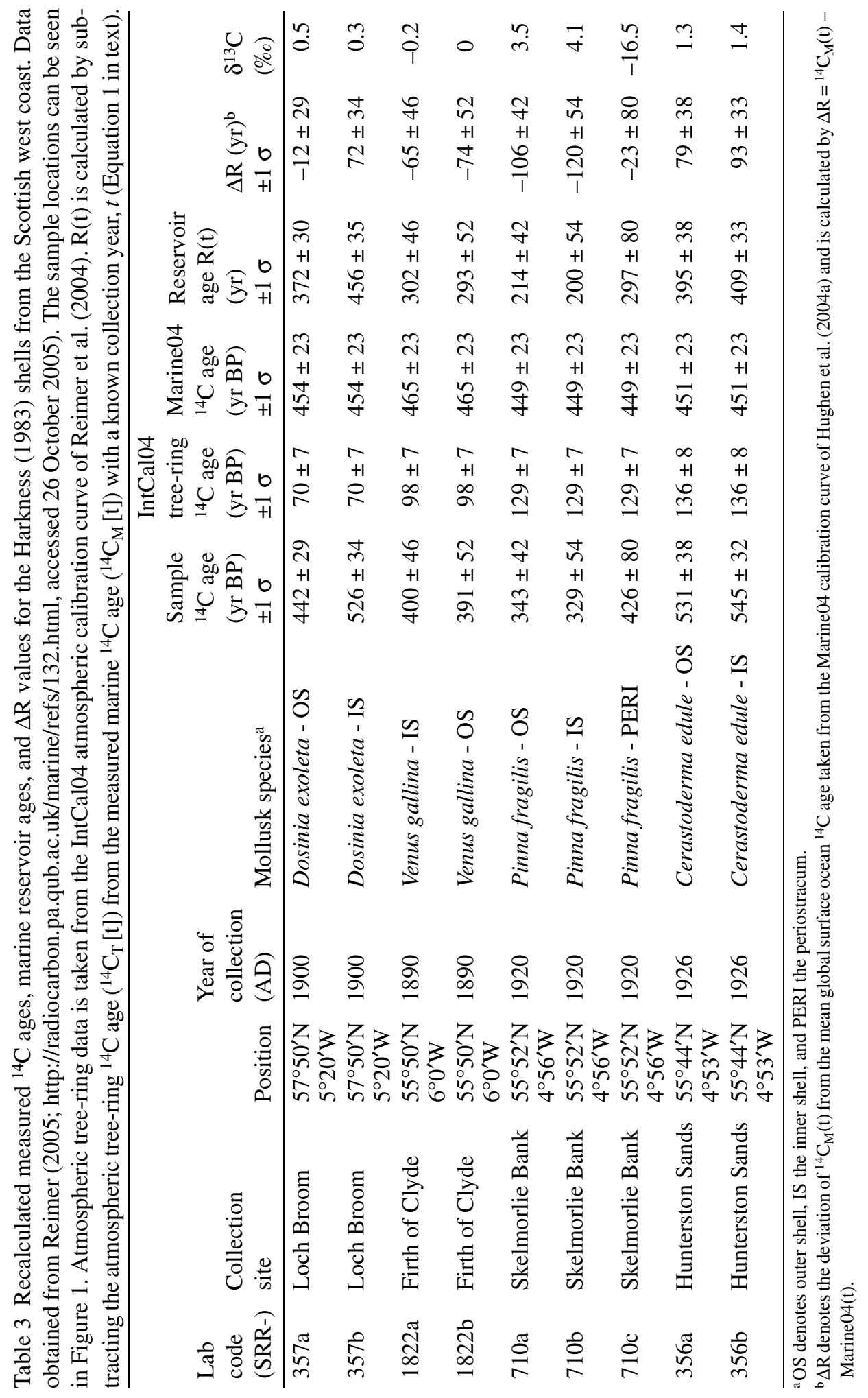


bon (DIC), whereas deposit-feeders may utilize old organic carbon from detritus. The shells used in this study were all bivalve filter-feeders, hence they should derive their carbon directly from seawater DIC. Ascough et al. (2005) suggested no significant species effect upon the ${ }^{14} \mathrm{C}$ content of marine mollusks in a study of archaeological material from a coastal location in the Outer Hebrides, Scotland, and it is unlikely that the shells used in this study or by Harkness (1983) show a speciesdependent effect on ${ }^{14} \mathrm{C}$ measurements.

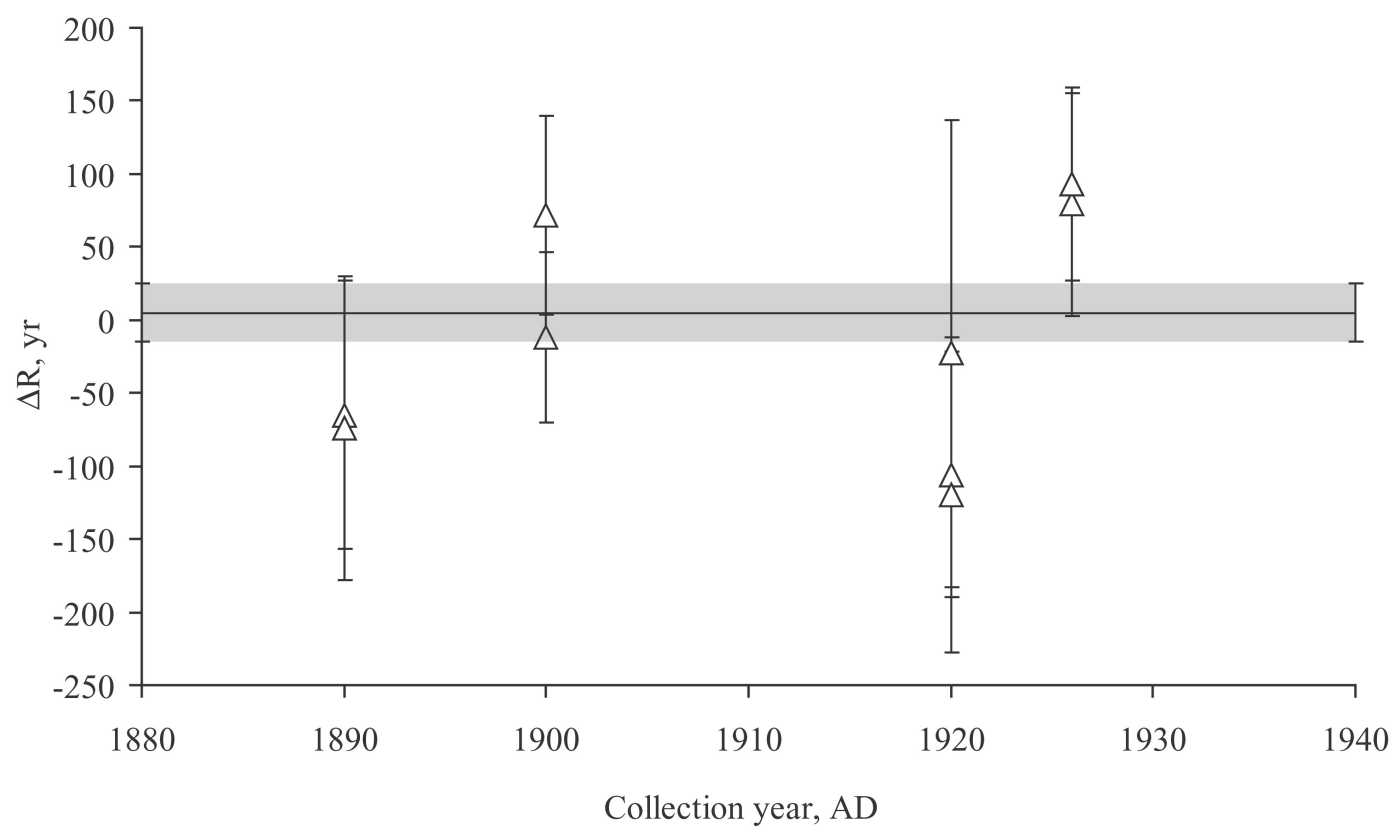

Figure 3 The $\Delta \mathrm{R}$ values of the Scottish west coast shells (unfilled triangles) from the Harkness (1983) study (data from Reimer 2005) along with measured ${ }^{14} \mathrm{C}$ age errors of $2 \sigma$. The thick black line and shaded box represent the weighted average of the $\Delta \mathrm{R}$ values with $2-\sigma$ error bars $(\Delta \mathrm{R}=5 \pm 10)$.

The averaged Harkness $\Delta \mathrm{R}$ data for whole-shell measurements are presented with the data from this study in Figure 4. These combined data show a weighted average $\Delta \mathrm{R}$ value of $-7 \pm 20 \mathrm{yr}$, including an averaged $\Delta \mathrm{R}$ value for the Loch Creran sample. The $\Delta \mathrm{R}$ value of the combined data is likely to approach 0 by the inclusion of the Hunterson Sands sample (SRR-356; Table 3). Hunterston Sands is located near the mouth of the Firth of Clyde (Figure 1), so one might expect to see less negative $\Delta \mathrm{R}$ values due to a greater influence of "older" coastal waters at this location. However, as Harkness (1983) points out, the Hunterston Sands and Skelmorlie Bank samples may have been influenced by pollution, since organic waste (containing unknown quantities of modern ${ }^{14} \mathrm{C}$ and ${ }^{14} \mathrm{C}$-free residues) was being dumped into the Clyde Sea at the time of the collection period (AD 1920). Since the Hunterston Sands sample (SRR-356) is the only sample to lie outside the acceptable statistical variance $(2 \sigma)$ of the data's weighted average $\Delta \mathrm{R}$ (Figure 3 ) and its validity of truly representing the natural regional $\Delta \mathrm{R}$ is in doubt (Harkness 1983), it has been omitted from the west Scottish weighted average $\Delta R$. Therefore, the new calculated weighted average of the "combined" $\Delta R$ is $-26 \pm 14 \mathrm{yr}$.

A Student's $t$ test (with the null hypothesis accepted in the $F$ test) shows that the "combined" $\Delta \mathrm{R}$ value of $-26 \pm 14 \mathrm{yr}$ is statistically different (with a confidence level $>95 \%$ ) from the $\Delta \mathrm{R}$ value of $17 \pm 14$ yr quoted by Harkness (1983; data from Reimer 2005) for UK coastal waters. Coastal and 


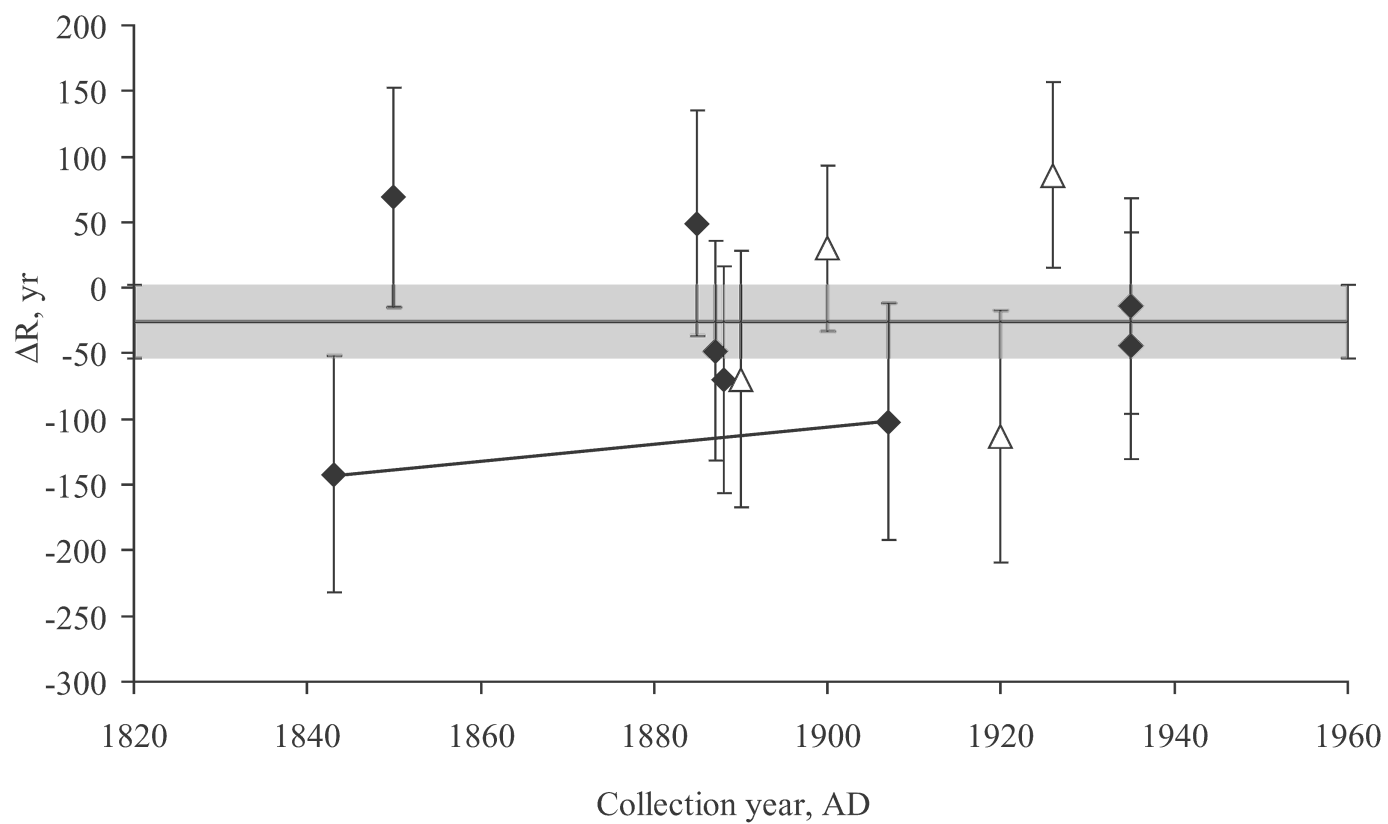

Figure $4 \Delta \mathrm{R}$ values for historical shells obtained from the coastal waters of W Scotland from this study (filled diamonds) and from the Harkness (1983) study (data from Reimer 2004; unfilled triangles). The linked data points represent the possible collection period of the Loch Creran shell. The thick black line and shaded box represent the weighted average of the $\Delta \mathrm{R}$ values with $2-\sigma$ error bars $(\Delta \mathrm{R}=-26 \pm 14$; including the averaged $\Delta \mathrm{R}$ value for the Loch Creran sample).

fjordic waters of the Scottish west coast exhibit significantly more negative $\Delta \mathrm{R}$ values due to the restricted connection with adjacent "older" shelf waters, high inputs of "younger" freshwater into the fjordic hydrography (e.g. Farmer and Freeland 1983), and the mixing of fjordic waters with coastal waters. Scottish sea lochs experience DWREs, i.e. basin water renewal, relatively frequently (Edwards and Sharples 1986); thus, the basin water stagnation sometimes seen in deeper Norwegian fjords (e.g. Mangerud 1972) is unlikely to be an additional source of "high apparent age" water masses to the fjordic hydrography.

The regional $\Delta \mathrm{R}$ value of $-26 \pm 14 \mathrm{yr}$ reported in this study for the NW coastal and fjordic waters of Scotland is in broad agreement with estimates of $\Delta \mathrm{R}(-33 \pm 93 \mathrm{yr})$ quoted by Reimer et al. (2002) for the region encompassing west Ireland, Scotland, and the Orkney Islands during the mid- to late Holocene. Bondevik et al. (1999) also reported a marine reservoir age of $380 \pm 32 \mathrm{BP}(\Delta \mathrm{R}=-20)$ for the west coast of Norway. Spatially, differences in regional $\Delta \mathrm{R}$ values (Table 1) typically arise due to local hydrography (e.g. Mangerud and Gulliksen 1975). For instance, the high positive $\Delta R$ values from the northern Norwegian Sea (Table 1) likely reflect the introduction of ${ }^{14} \mathrm{C}$-depleted deep waters and may be influenced by the restricted ${ }^{14} \mathrm{C}$ atmosphere-surface ocean exchange of polar water masses due to regional sea-ice cover, whereas negative $\Delta \mathrm{R}$ values in the seas around S Norway, W Sweden, and E Denmark suggest a significant influx of Baltic Sea brackish water into the local hydrography (Table 1). Negative $\Delta \mathrm{R}$ values from coastal locations such as NW Scotland and W Norway may also be explained by the mixing of "young" freshwater surface runoff with coastal water masses that are likely to be dominated by a strong Atlantic surface ocean water component with a $\Delta \mathrm{R}$ value close to 0 (e.g. Mangerud and Gulliksen 1975). However, the $\Delta \mathrm{R}$ of $-26 \pm$ $14 \mathrm{yr}$ presented here is statistically different from the $\Delta \mathrm{R}$ of $-79 \pm 17 \mathrm{yr}$ reported by Ascough et al. (2004) for coastal locations in north and west Scotland based on the dating of paired marine and ter- 
restrial material within archaeological sites dated at 2000 BP. Temporal variations at any location are likely to be complex due to variations in ${ }^{14} \mathrm{C}$ production and changes in regional circulation, both of which would significantly influence the ${ }^{14} \mathrm{C}$ activity of surface ocean waters (e.g. Weidman and Jones 1993; van Geel et al. 2003; Hughen et al. 2004b).

\section{CONCLUSION}

The igneous bedrock geology of NW Scotland, the thin and poorly developed soils, and the steep slopes that rapidly translate rainfall into surface runoff (Black and Cranston 1995) mean that the freshwater inputs into sea lochs should typically have an isotopic signal close to atmospheric ${ }^{14} \mathrm{C} /$ ${ }^{12} \mathrm{C}$ (Broecker and Walton 1959). In these settings, the influences of ${ }^{14} \mathrm{C}$-deficient carbon derived from humus or carbonate bedrock are likely to be small.

A regional $\Delta \mathrm{R}$ value of $-26 \pm 14 \mathrm{yr}$ has been determined for the sea loch (fjordic) and coastal waters of NW Scotland, which is statistically different (at a confidence level $>95 \%$ ) from the $\Delta \mathrm{R}$ value of $17 \pm 14 \mathrm{yr}$ reported for UK coastal waters (Harkness 1983) and in good agreement with the $-33 \pm$ $93 \mathrm{yr}$ reported by Reimer et al. (2002). This negative $\Delta \mathrm{R}$ supports the hypothesis that high freshwater inputs into NW Scottish coastal waters typically produce marine ${ }^{14} \mathrm{C}$ reservoir ages, $\mathrm{R}(\mathrm{t})$, "younger" than the global average surface ocean ${ }^{14} \mathrm{C}$ reservoir age (Stuiver and Braziunas 1993), with a combined $\mathrm{R}(\mathrm{t})$ of $323 \pm 8 \mathrm{yr}$ (including an averaged $\mathrm{R}[\mathrm{t}]$ for Loch Creran and excluding data from Hunterson Sands). Therefore, a regional marine reservoir age correction factor of $\Delta R=-26 \pm$ $14 \mathrm{yr}$ should be applied to modern (i.e. pre-bomb but not prehistoric) marine ${ }^{14} \mathrm{C}$ dates from the $\mathrm{NW}$ coast of Scotland.

\section{ACKNOWLEDGMENTS}

We would like to thank Ann Berith Jensen and Vibeke Jensen from the AMS ${ }^{14} \mathrm{C}$ Dating Laboratory, University of Aarhus, Denmark, for their technical assistance. Sankurie Pye (National Museum of Scotland, Edinburgh, Scotland) assisted us in obtaining museum-archived shells. AGC acknowledges financial support from the Russell Trust, University of St. Andrews, and the Scottish International Education Trust. The AMS ${ }^{14} \mathrm{C}$ dates were funded by the European Framework V Project HOLSMEER.

\section{REFERENCES}

Aitken MJ. 1990. Science-Based Dating in Archaeology. London: Longman. 274 p.

Allen GL, Simpson JH. 1998. Deep water inflows to Upper Loch Linnhe. Estuarine Coastal and Shelf Science 47(4):487-98.

Andersen GJ, Heinemeier J, Nielsen HL, Rud N, Thomsen MS, Johnsen S, Sveinbjörnsdóttir Á, Hjartarson Á. 1989. AMS ${ }^{14} \mathrm{C}$ dating on the Fossvogur sediments, Iceland. Radiocarbon 31(3):592-600.

Ascough PL, Cook GT, Dugmore AJ, Barber J, Higney E, Scott EM. 2004. Holocene variations in the Scottish marine radiocarbon reservoir effect. Radiocarbon 46(2):611-20.

Ascough PL, Cook GT, Dugmore AJ, Scott EM, Freeman SPHT. 2005. Influence of mollusk species on marine $\Delta \mathrm{R}$ determinations. Radiocarbon 47(3):433-40.

Austin WEN, Inall ME. 2002. Deep-water renewal in a Scottish fjord: temperature, salinity and oxygen iso- topes. Polar Research 21(2):251-7.

Austin WEN, Bard E, Hunt JB, Kroon D, Peacock JD. 1995. The ${ }^{14} \mathrm{C}$ age of the Icelandic Vedde Ash-implications for Younger Dryas marine reservoir age corrections. Radiocarbon 37(1):53-62.

Bard E. 1998. Geochemical and geophysical implications of the radiocarbon calibration. Geochimica et Cosmochimica Acta 62(12):2025-38.

Bard E, Arnold M, Hamelin B, Tisnerat-Laborde N, Cabioch G. 1998. Radiocarbon calibration by means of mass spectrometric ${ }^{230} \mathrm{Th} /{ }^{234} \mathrm{U}$ and ${ }^{14} \mathrm{C}$ ages of corals: an updated database including samples from Barbados, Mururoa and Tahiti. Radiocarbon 40(3):108592.

Berkman PA, Forman SL. 1996. Pre-bomb radiocarbon and the reservoir correction for calcareous marine species in the Southern Ocean. Geophysical Research Letters 23(4):363-6. 
Black AR, Cranston MD. 1995. River flow gauging station data usage and network evolution in Scotland. In: Proceedings of British Hydrological Society 5th National Hydrology Symposium, Edinburgh. 6.19-6.25.

Bondevik S, Birks HH, Gulliksen S, Mangerud J. 1999. Late Weichselian marine ${ }^{14} \mathrm{C}$ reservoir ages at the western coast of Norway. Quaternary Research 52(1): 104-14.

Broecker WS, Olson EA. 1961. Lamont radiocarbon measurements VIII. Radiocarbon 3:176-204.

Broecker WS, Walton A. 1959. The geochemistry of ${ }^{14} \mathrm{C}$ in fresh-water systems. Geochimica et Cosmochimica Acta 16:15-38.

Edwards A, Sharples F. 1986. Scottish Sea Lochs: A Catalogue. Oban/Peterborough: Scottish Marine Biological Association/Nature Conservancy Council. 110 p.

Engstrand LG. 1965. Stockholm natural radiocarbon measurements VI. Radiocarbon 7:257-90.

Eiríksson J, Larsen G, Knudsen KL, Heinemeier J, Simonarson LA. 2004. Marine reservoir age variability and water mass distribution in the Iceland Sea. Quaternary Science Reviews 23(20-22):2247-68.

Facorellis Y, Maniatis Y, Kromer B. 1998. Apparent ${ }^{14} \mathrm{C}$ ages of marine mollusk shells from a Greek island: calculation of the marine reservoir effect in the Aegean Sea. Radiocarbon 40(2):963-73.

Farmer DM, Freeland HJ. 1983. The physical oceanography of fjords. Progress in Oceanography 12(2): 147-219.

Gillibrand PA, Turrell WR, Elliott AJ. 1995. Deep-water renewal in the upper basin of Loch Sunart, a Scottish fjord. Journal of Physical Oceanography 25(6):1488503.

Gillibrand PA, Turrell WR, Moore DC, Adams RD. 1996. Bottom water stagnation and oxygen depletion in a Scottish sea loch. Estuarine Coastal and Shelf Science 43(2):217-35.

Gillibrand PA, Cage AG, Austin WEN. 2005. A preliminary investigation of basin water response to climate forcing in a Scottish fjord: evaluating the influence of the NAO. Continental Shelf Research 25(5-6):57187.

Håkansson S. 1969. University of Lund radiocarbon dates II. Radiocarbon 11(2):430-50.

Håkansson S. 1970. University of Lund radiocarbon dates III. Radiocarbon 12(2):534-52.

Håkansson S. 1983. University of Lund radiocarbon dates XVI. Radiocarbon 25(3):875-91.

Håkansson S. 1984. A reservoir age for the coastal waters of Iceland. Geologiska Föreningens I Stockholm Förhandlinger 105:64-7.

Håkansson S. 1987. University of Lund radiocarbon dates XX. Radiocarbon 29(3):353-79.

Harkness DD. 1983. The extent of natural ${ }^{14} \mathrm{C}$ deficiency in the coastal environment of the United Kingdom. In: Mook WG, Waterbolk HT, editors. Proceedings of the Symposium ${ }^{14} \mathrm{C}$ and Archaeology. PACT 8:351-64.
Heier-Nielsen S, Heinemeier $\mathrm{J}$, Nielsen HL, Rud $\mathrm{N}$. 1995. Recent reservoir ages for Danish fjords and marine waters. Radiocarbon 37(3):875-82.

Hughen KA, Baillie MGL, Bard E, Beck JW, Bertrand CJ, Blackwell PG, Buck CE, Burr GS, Cutler KB, Damon PE, Edwards RL, Fairbanks RG, Friedrich M, Guilderson TP, Kromer B, McCormac FG, Manning S, Bronk Ramsey C, Reimer PJ, Reimer RW, Remmele S, Southon J, Stuiver M, Talamo S, Taylor FW, van der Plicht J, Weyhenmeyer CE. 2004a. Marine04 marine radiocarbon age calibration, 0-26 cal kyr BP. Radiocarbon 46(3):1059-86.

Hughen K, Lehman S, Southon J, Overpeck J, Marchal O, Herring C, Turnbull J. 2004b. ${ }^{14} \mathrm{C}$ activity and global carbon cycle changes over the past 50,000 years. Science 303(5655):202-7.

Kristensen DK, Sejrup HP, Haflidason H, Berstad IM, Mikalsen G. 2004. Eight-hundred-year temperature variability from the Norwegian continental margin and the North Atlantic thermohaline circulation. Paleoceanography 19(2):PA2007.

Krog H, Tauber H. 1974. C-14 chronology of late- and post-glacial marine deposits in north Jutland. Danmarks geologiske Undersøgelse, Årbog 1973:93-105.

Mangerud J. 1972. Radiocarbon dating of marine shells, including a discussion of apparent age of recent shells from Norway. Boreas 1:149-72.

Mangerud J, Gulliksen S. 1975. Apparent radiocarbon ages of recent marine shells from Norway, Spitsbergen, and Arctic Canada. Quaternary Research 5(2): 263-73.

Mikalsen G, Sejrup HP, Aarseth I. 2001. Late-Holocene changes in ocean circulation and climate: foraminiferal and isotopic evidence from Sulafjord, western Norway. The Holocene 11(4):437-46.

Mook WG, Vogel JC. 1968. Isotopic equilibrium between shells and their environment. Science 159:874-5.

Olsson IU. 1980. Content of ${ }^{14} \mathrm{C}$ in marine mammals from northern Europe. Radiocarbon 22(3):662-75.

Olsson IU, El-Gammal S, Göksu Y. 1969. Uppsala natural radiocarbon measurements IX. Radiocarbon 11(2): $515-44$.

Reimer PJ. 2005. Marine Reservoir Correction Database. Accessible at http://radiocarbon.pa.qub.ac.uk/marine. accessed on 26 October 2005.

Reimer PJ, McCormac FG, Moore J, McCormick F, Murray EV. 2002. Marine radiocarbon reservoir corrections for the mid- to late Holocene in the eastern subpolar North Atlantic. The Holocene 12(2):129-35.

Reimer PJ, Baillie MGL, Bard E, Bayliss A, Beck JW, Bertrand CJ, Blackwell PG, Buck CE, Burr GS, Cutler KB, Damon PE, Edwards RL, Fairbanks RG, Friedrich M, Guilderson TP, Hogg AG, Hughen KA, Kromer B, McCormac FG, Manning S, Bronk Ramsey C, Reimer RW, Remmele S, Southon J, Stuiver M, Talamo S, Taylor FW, van der Plicht J, Weyhenmeyer CE. 2004. IntCal04 terrestrial radiocarbon age calibration, 0-26 
cal kyr BP. Radiocarbon 46(3):1029-58.

Siani G, Paterne M, Arnold M, Bard E, Metivier B, Tisnerat N, Bassinot F. 2000. Radiocarbon reservoir ages in the Mediterranean Sea and Black Sea. Radiocarbon 42(2):271-80

Spiker EC. 1980. The behavior of ${ }^{14} \mathrm{C}$ and ${ }^{13} \mathrm{C}$ in estuarine water: effects of in situ $\mathrm{CO}_{2}$ production and atmospheric exchange. Radiocarbon 22(3):647-54.

Stuiver M, Braziunas TF. 1993. Modeling atmospheric ${ }^{14} \mathrm{C}$ influences and ${ }^{14} \mathrm{C}$ ages of marine samples to 10,000 BC. Radiocarbon 35(1):137-89.

Stuiver M, Polach HA. 1977. Discussion: reporting of ${ }^{14} \mathrm{C}$ data. Radiocarbon 19(3):355-63.

Stuiver M, Pearson GW, Braziunas T. 1986. Radiocarbon age calibration of marine samples back to $9000 \mathrm{cal} \mathrm{yr}$ BP. Radiocarbon 28(2B):980-1021.

van Geel B, van der Plicht J, Renssen H. 2003. Major $\Delta^{14} \mathrm{C}$ excursions during the late glacial and early Holocene: changes in ocean ventilation or solar forcing of climate change? Quaternary International 105:716.

Vogel JS, Southon JR, Nelson DE, Brown TA. 1984. Performance of catalytically condensed carbon for use in accelerator mass spectrometry. Nuclear Instruments and Methods in Physics Research B 5:289-93.

Waelbroeck C, Duplessy JC, Michel E, Labeyrie L, Paillard D, Duprat J. 2001. The timing of the last deglaciation in North Atlantic climate records. Nature 412(6848):724-7.

Weidman CR. 1995. Development and application of the mollusc Arctica islandica as a paleoceanographic tool for the North Atlantic Ocean [PhD dissertation]. MIT/ WHOI, Joint Program in Oceanography, Massachusetts Institute of Technology, Cambridge, MA and Woods Hole Oceanographic Institution, Woods Hole, USA. 203 p.

Weidman CR, Jones GA. 1993. A shell-derived time history of bomb ${ }^{14} \mathrm{C}$ on Georges Bank and its Labrador Sea implications. Journal of Geophysical ResearchOceans $98(\mathrm{C} 8): 14,577-88$.

Yoneda M, Kitagawa H, van der Plicht J, Uchida M, Tanaka A, Uehiro T, Shibata Y, Morita M, Ohno T. 2000. Pre-bomb marine reservoir ages in the western North Pacific: preliminary result on Kyoto University collection. Nuclear Instruments and Methods in Physics Research B 172:377-81. 